\title{
Management of Children with Severe COVID-19 in a Pediatrics Unit in Istanbul: A Retrospective Study
}

\author{
- Ayşe Karaaslan, ${ }^{1}$ (1) Ceren Çetin,, (1) Yasemin Akın, ${ }^{2}$ \\ (1) Cem Murat Bal, ${ }^{2}$ (1) Recep Demirhan ${ }^{3}$
}

\section{'Department of Pediatric Infectious Diseases, Kartal Dr. Lütfi Kırdar City Hospital, İstanbul, Turkey 2Department of Pediatrics, Kartal Dr. Lütfi Kırdar City Hospital, İstanbul, Turkey \\ ${ }^{3}$ Department of Chest Surgery, Kartal Dr. Lütfi Kırdar City Hospital, İstanbul, Turkey}

Submitted: 06.07.2021 Accepted: 12.10.2021

Correspondence: Yasemin Akın, Kartal Dr. Lütfi Kırdar Şehi Hastanesi, Çocuk Sağlığı ve Hastalıkları Kliniği, İstanbul, Turkey E-mail: jasminetr@hotmail.com

arpra

Keywords: Children; management; severe COVID-19.

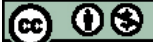

his work is licensed under a Creative Commons Attribution-NonCommercial 4.0 International License.

\begin{abstract}
Objective: SARS-CoV-2 is a probable causative agent of severe disease both in children and adults. In this study, we aimed to evaluate the management of hospitalized severe pediatric COVID- 19 patients.
\end{abstract}

Methods: Data on the management of 21 children under the age of 18 who were hospitalized with severe COVID-19 between March 2020 and May 2020 were included in this study.

Results: A total of 1109 patients, including 888 outpatients and 221 inpatients, were included in this study. 91 (4I.I\%) of the 221 hospitalized children were PCR positive for SARS-CoV-2. 21 (23\%) of 91 COVID- 19 patients were considered severe COVID-19. 10 (47.6\%) were females and II (52.4\%) were males, with a mean \pm standard deviation (SD) age of $14.4 \pm 2.7$ years (range; 9 years-17.6 years). The most prevalent symptoms at admission were fever (80.9\%), cough (76.1\%), shortness of breath (23.8\%) and myalgia (23.8\%). 4 (19\%) of 21 patients had underlying diseases. 19 (90.4\%) patients were in close contact with confirmed cases in the family. All patients had typical findings on lung computed tomography (CT) and the major CT abnormalities observed were ground-glass opacities. Two patients who needed respiratory support received favipiravir treatment. The mean hospital stay was $7.34 \pm 2.65$ (5-16) days. Clinical improvement was achieved in all patients.

Conclusion: The clinical course of COVID-19 in children is milder and has a better prognosis than adults, but it should be kept in mind that severe cases are defined in the pediatric patient group and these patients should be followed closely.

\section{INTRODUCTION}

Coronaviruses (CoVs) are enveloped positive-stranded RNA viruses that belong to the Coronaviridea family and compose the Orthocoronavirinae subfamily. The most common human coronaviruses are; HCoV-HKUI, HCoVNL63, HCoV-OC43 and HCoV-229E. In December 2019, a novel coronavirus was recognised as the causative agent of severe cases of pneumonia originating from Wuhan in Hubei province, China. ${ }^{[1]}$ On February II, 2020, this virus was named "Severe Acute Respiratory Syndrome Coronavirus 2 (SARS-CoV-2)" by the International Committee on Taxonomy of Viruses (ICTV), because it is genetically related to the coronavirus responsible for the SARS outbreak of 2003, and thereafter the World Health Organisation (WHO) announced the disease caused by SARS-CoV-2 as "Coronavirus disease-2019 (COVID-19)".[2] After sever- al weeks, on March II, 2020, WHO pointed that there were more than II8.000 cases, and 4.29I deaths in II4 countries and therefore declared that COVID- 19 could be qualified as a pandemic. ${ }^{[3]}$ In Turkey, the first case was detected on II March 2020 and a total of 135,569 cases and 3689 deaths were reported on 8 May, 2020. ${ }^{[4]}$

Limited data are available and still unclear on clinical patterns of the COVID-19 in pediatric populations. However, it is known that children have milder symptoms and a better prognosis compared to adult patient groups. ${ }^{[5]}$ Liu et al. ${ }^{[6]}$ reported that the main symptoms in children were fever, cough, and vomiting. Diarrhea has been reported as a symptom in 2-10\% of COVID-19 cases in different studies. ${ }^{[7,8]}$ And in infant groups, fever, lethargy and shortness of breath are described as symptoms. ${ }^{[9]}$ Although most infected children have milder symptoms than adults, available data suggest that they can become severely ill. ${ }^{[10]}$ 
Therefore, we can say that there is a wide range of symptoms in the children group.

Treatment suggestions for COVID-19 in children are mostly adapted from adult treatment protocols. Because of the common mild course of pediatric COVID-19, closer follow-up observation and supportive care are suggested for the majority of cases.

Due to the lack of data investigated in severe children patients with COVID-19, we aimed to evaluate the clinical features, laboratory findings, radiologic findings, and management of children with severe COVID-19.

\section{MATERIALS AND METHODS}

This retrospective descriptive study was conducted in a 1000-bed tertiary education and research hospital, one of the designated hospitals for COVID-19, in Istanbul, Turkey, between March 2020 and May 2020.

The participants were identified through the department's patient files archive (age, sex, potential source of infection, laboratory results, computed tomography (CT) findings, respiratory support, treatment strategies). A total of II09 patients, 888 outpatients and 22I inpatients, were recruited in this study. A nasopharyngeal swab was collected from a single nostril according to the Turkish Ministry of Health COVID-19 Pediatric Patient Management and Treatment Guideline. ${ }^{[1]}$ At the beginning of the study, nasopharyngeal swabs were transferred to the reference laboratory, Turkish Public Health Agency, and after Aprill6, 2020 nasopharyngeal swabs were collected in our tertiary education and research hospital.

We defined severe COVID-19 as children with severe pneumonia with typical computed tomography findings. Pneumonia was classified according to age (infants/children) and clinical symptoms (mild-moderate-severe). ${ }^{[2,13]}$ In this study, the minimum age of the patients was 9 years old, so we implemented the criteria for children. The criteria for severe pneumonia were as folows; fever $>38.5^{\circ} \mathrm{C}$ \pm respiratory rate $>50$ breaths/minute \pm saturation $\leq 92 \%$ in room air \pm apnea \pm nasal flaring \pm lethargy \pm grunting \pm cyanosis \pm chest retractions \pm poor feeding \pm dehydration \pm shock. Laboratory confirmation of SARS-CoV-2 was performed using RT-PCR.

We administered favipiravir $1600 \mathrm{mg} /$ dose, twice daily on day I and $600 \mathrm{mg} /$ dose, twice daily on days 2 to 5 to children who only needed respiratory support. ${ }^{[14]}$

This study was approved by the Clinical Research Ethics Committee of our institution. Written informed consent was obtained from all participants' parents/ guardians on admission for all diagnostic tests and treatment protocol.

\section{Statistical analysis}

In statistical analyses, we documented all available medical information including age, sex, clinical features, CT findings, laboratory results, respiratory support, and mortality in Microsoft Excel. Descriptive statistics were expressed as mean \pm standard deviation for normally distributed data, whereas median \pm interquartile ranges were stated for non-normally distributed data. Statistical analyses were performed using Statistical Package for the Social Sciences software version 12.0 (SPSS Inc., Chicago, III., USA).

\section{RESULTS}

Of the total 91 confirmed COVID- 19 hospitalized children in our pediatric unit, 21 (23\%) were included in this study due to their severe COVID-19 condition. There were IO (47.6\%) females and II (52.4\%) males with a mean士standard deviation (SD) age of $14.4 \pm 2.7$ years (range, 9 years-17.6 years). SARS-CoV-2 infection was verified by RT-PCR results in all patients. Patients were classified according to age as follows: $<5$ years, $5-15$ years, and $\geq 15$ years. There were no severe children under 5 years of age, $12(57.1 \%)$ children were in the $5-15$ years age group and $9(42.9 \%)$ children were in the $\geq 15$ age group.

The most prevalent symptoms at presentation were fever (80.9\%), cough $(76.1 \%)$, shortness of breath $(23,8 \%)$, and myalgia (23.8\%). Two patients with fever had also headache. One patient had a sore throat and one patient had abdominal pain. Two patients developed, shortness of breath and hypoxemia during hospitalization and needed respiratory support. Two children had hemoptysis and one child had taste loss. The most persistent symptom was fever over $>38^{\circ} \mathrm{C}$. $19(90.4 \%)$ patients were in close contact with confirmed cases in the family.

All patients were screened with computed tomography because of abnormal findings on chest radiography. All children (100\%) had typical CT findings. The major CT abnormalities observed were ground-glass opacities (90.4\%) and mixed ground-glass opacity and consolidation lesions were detected in two patients. I I (52.4\%) patients had bilateral ground-glass opacities and $10(47.6 \%)$ patients had unilateral ground-glass opacities.

In two patients, favipiravir therapy was used because they clinically worsened under this therapy and required respiratory support due to hypoxemia. They also received antibiotic therapy with teicoplanin and meropenem. One of them was a 17-year-old girl, who presented with fever, shortness of breath and chest pain, had the following laboratory findings at the time of admission; leucocyte: $4500 / \mathrm{mm}^{3}$ (4800-10.800), lymphocyte: $800 / \mathrm{mm}^{3}$ (I.3-2.0), platelet: $189.000 / \mathrm{mm}^{3}$ (130.000-400.000), Alanine transaminase (ALT): $17 \mathrm{U} / \mathrm{L}(0-35)$, Aspartate transaminase (AST): $19 \mathrm{U} / \mathrm{L}$ (0-35), creatinine: $0.38 \mathrm{mg} / \mathrm{dl}$ (0.16-0.39), lactate dehydrogenase (LDH): $237 \mathrm{U} / \mathrm{L}$ (127-403), Creatinine kinase (CK): 65U/L (0-145), Troponin: <0.003 $\mu \mathrm{g} / \mathrm{L}$ (0-0.0l4), ferritin: $29 \mu \mathrm{g} / \mathrm{L}$ (5.8-274), C-reactive protein: $<3.11 \mathrm{mg} / \mathrm{L}(0-3.5)$ and D-dimer: $360 \mu \mathrm{g} / \mathrm{L}(0.0000 \mathrm{I}-500)$. She had a worse clinical course during her hospitalization and received respiratory support (high-flow nasal oxygen) and her lymphocyte count was decreased to $500 / \mathrm{mm}^{3}$ and her platelet count was decreased to $119.000 / \mathrm{mm}^{3}$. On 
the other hand, C-reactive protein is elevated to $67 \mathrm{mg} / \mathrm{L}$, D-dimer was elevated to $1480 \mu \mathrm{g} / \mathrm{L}$, and ferritin is elevated to $126 \mu \mathrm{g} / \mathrm{L}$. The other patient who required respiratory support was a 13-year-old boy who presented with fever, cough and shortness of breath, and had the following laboratory findings at the time of admission; leucocyte: 9900/ $\mathrm{mm}^{3}$ (4800-10.800), lympocyte: $3900 / \mathrm{mm}^{3}$ (1.3-2.0), platelet: 4I5.000/mm (130.000-400.000), ALT: 46U/L (035), AST: $36 \mathrm{U} / \mathrm{L}(0-35)$, creatinine: $0.83 \mathrm{mg} / \mathrm{dl}(0.16-0.39)$, lactate dehydrogenase (LDH): $288 \mathrm{U} / \mathrm{L}$ (I27-403), CK (creatinine kinase): $60 \mathrm{U} / \mathrm{L}(0-145)$, Troponin: $<0.003 \mu \mathrm{g} / \mathrm{L}$ (0-0.0l4), ferritin: $200.8 \mu \mathrm{g} / \mathrm{L}$ (5.8-274), C-reactive protein: $17.1 \mathrm{mg} / \mathrm{L}(0-3.5)$ and D-dimer: $1050 \mu \mathrm{g} / \mathrm{L}$ (0.0000 I500). He had a worse clinical course during his hospitalization and received respiratory support (high-flow nasal oxygen) and his lymphocyte count was decreased to 900/ $\mathrm{mm}^{3}$. On the other hand, C-reactive protein is elevated to $29.5 \mathrm{mg} / \mathrm{L}$, and ferritin is elevated to $991.8 \mu \mathrm{g} / \mathrm{L}$. In this patient, we analyzed IL-6 and found it as high as $91.46 \mathrm{pg} / \mathrm{ml}$.

Blood indexes were analyzed at the admission and the median (IQR) WBC count was $5450 / \mathrm{mm}^{3}$ (4525-6425), the median lymphocyte (IQR) count was $1550 / \mathrm{mm}^{3}$ (I225-2075), the mean hemoglobin level was I3.2 $\pm 1.3 \mathrm{~g} /$ $\mathrm{dl}$ (range; Il. I-l6.0 g/dl), the mean platelet volume (MPV) was $8.23 \pm 1.07$ (range; 7-II.2 fL) and the median (IQR) platelet count was $220.000 / \mathrm{mm}^{3}(182.500-265.500)$. The median AST level was $22 \mathrm{U} / \mathrm{L}$ (17.5-29), the median (IQR) ALT was $16.5 \mathrm{U} / \mathrm{L}$ (12.25-32.5), the median (IQR) lac- tate dehydrogenase (LDH) was $214 \mathrm{U} / \mathrm{L}$ (I70.5-235.75), the median (IQR) CK was $84.5 \mathrm{U} / \mathrm{L}$ (55.25-126.75), the median (IQR) creatinine was $0.50 \mathrm{mg} / \mathrm{dl}(0.4 \mathrm{I}-0.76)$ and the median (IQR) ferritin was $43.7 \mu \mathrm{g} / \mathrm{L}$ (32.7-83). At the admission, C-reactive protein was negative $(<3.1 \mathrm{I})$ in 12 (57.1\%) patients and positive in $9(42.9 \%)$ patients. The median (IQR) C-reactive protein was $12 \mathrm{mg} / \mathrm{L}$ (6.I-I7.7). The median D-dimer level at the admission was $460 \mu \mathrm{g} / \mathrm{L}$ (360-620) (Table I).

Four children (19\%) had underlying diseases. One patient had chronic renal diseases, one patient had asthma, one patient had hypertension, and one patient was with autism. The blood cultures were available for all patients and all cultures resulted to be negative. The mean hospital stay was $7.34 \pm 2.65(5-16)$ days. None of the patients died and all patients achieved clinical recovery without any sequelae.

\section{DISCUSSION}

There is a lack of data regarding the clinical, radiological, laboratory, and management of severe COVID-19 pediatric patients. In this study, we report the favorable clinical outcomes of 21 children with severe COVID- 19 in a tertiary hospital unit.

COVID- 19 appears to be milder in children than in adults. Lu et al. ${ }^{[15]}$ reported the clinical features and radiological findings of 171 children with SARS-CoV-2 infection and

Table I. The laboratory findings of children with severe COVID-19

\begin{tabular}{|c|c|c|c|c|c|c|c|c|c|c|c|c|}
\hline Cases & $\begin{array}{c}\text { WBC } \\
\left(/ \mathrm{mm}^{3}\right)\end{array}$ & $\begin{array}{c}\text { Lympocyte } \\
\left(/ \mathrm{mm}^{3}\right)\end{array}$ & $\begin{array}{c}\text { Hb } \\
\text { (g/dl) }\end{array}$ & $\begin{array}{c}\text { Platelet } \\
\left(/ \mathrm{mm}^{3}\right)\end{array}$ & $\begin{array}{c}\text { MPV } \\
\text { (fL) }\end{array}$ & $\begin{array}{c}\text { Creatinine } \\
\text { (mg/dL) }\end{array}$ & $\begin{array}{c}\text { ALT } \\
\text { (U/L) }\end{array}$ & $\begin{array}{c}\text { AST } \\
\text { (U/L) }\end{array}$ & $\begin{array}{l}\text { LDH } \\
\text { (U/L) }\end{array}$ & $\begin{array}{c}\text { CK } \\
(\mathrm{U} / \mathrm{L})\end{array}$ & $\begin{array}{c}\text { Ferritin } \\
(\mu \mathrm{g} / \mathrm{L})\end{array}$ & $\begin{array}{c}\text { D-dimer } \\
\text { ( } \mu \mathrm{g} / \mathrm{L})\end{array}$ \\
\hline 1 & 4700 & 1000 & 12.3 & 192000 & 7.6 & 0.39 & 12 & 17 & 178 & 37 & 34.3 & 810 \\
\hline 2 & 5600 & 1500 & 11.7 & 65000 & 9.1 & 0.83 & 30 & 30 & 218 & 263 & 43.7 & 460 \\
\hline 3 & 3500 & 200 & 11.8 & 123000 & 10.9 & 0.38 & 14 & 16 & 237 & 85 & 126.6 & 360 \\
\hline 4 & 4600 & 1100 & 14.9 & 115000 & 11.2 & 0.62 & 14 & 22 & 266 & 105 & 100.5 & 1050 \\
\hline 5 & 3200 & 1300 & 12.7 & 243000 & 7.5 & 0.37 & 3 & 12 & 147 & 38 & 40.6 & 480 \\
\hline 6 & 5300 & 1100 & 12.9 & 198000 & 7.8 & 0.48 & 9 & 19 & $16 \mid$ & 77 & 23.5 & 460 \\
\hline 7 & 6800 & 1900 & 11.1 & 296000 & 8.3 & 0.51 & 13 & 19 & 195 & 52 & 32.7 & 670 \\
\hline 8 & 5800 & 1400 & 14.6 & 190000 & 9.3 & 0.41 & 12 & 21 & 155 & 50 & 26.6 & 380 \\
\hline 9 & 5600 & 600 & 12.1 & 244000 & 7 & 0.62 & 15 & 21 & 204 & 89 & 61 & 360 \\
\hline 10 & 4900 & 1500 & 14.1 & 180000 & 7.6 & 0.97 & 40 & 29 & 232 & 268 & 219 & 420 \\
\hline II & 6500 & 3300 & 13.2 & 368000 & 7.5 & 0.41 & 33 & 26 & 206 & 98 & 91.2 & 760 \\
\hline 12 & 4500 & 1840 & 12.9 & 159000 & 8.5 & 3.04 & 9 & 16 & 136 & 103 & 172 & 180 \\
\hline 13 & 7100 & 3180 & 12.7 & 330000 & 7 & 0.77 & 15 & 16 & 178 & 134 & 34.7 & 110 \\
\hline 14 & 6900 & 2660 & 12.9 & 295000 & 8.4 & 0.5 & 78 & 15 & 168 & 84 & 80.7 & 310 \\
\hline 15 & 4100 & 1600 & 11.5 & 35000 & 9.7 & 0.43 & 18 & 38 & 403 & 54 & 56 & 620 \\
\hline 16 & 4900 & 1300 & 16 & 226000 & 7.2 & 0.44 & 83 & 62 & 213 & 99 & 42 & 400 \\
\hline 17 & 12000 & 1500 & 13.1 & 255000 & 7.5 & 0.83 & 46 & 36 & 288 & 60 & 900 & 480 \\
\hline 18 & 8200 & 3100 & 14.7 & 249000 & 8.9 & 0.62 & 23 & 26 & 243 & 239 & 83 & 530 \\
\hline 19 & 4400 & 1750 & 14.2 & 247000 & 7.6 & 0.5 & 9 & 14 & 127 & 38 & 25 & 260 \\
\hline 20 & 5700 & 2100 & 14.6 & 451000 & 7.9 & 0.53 & 31 & 20 & 219 & 72 & 72.5 & 370 \\
\hline 21 & 4000 & 2200 & 14.6 & 321000 & 8.2 & 0.3 & 14 & 45 & 319 & 546 & 5.8 & 850 \\
\hline
\end{tabular}

WBC: White Blood Cell; Hb: Hemoglobin; MPV: Mean Platelet Volume; ALT: Alanine transaminase; AST: Aspartate transaminase; LDH: Lactate dehydrogenase; CK: Creatinine kinase. 
showed that cough and fever were the most common symptoms and ground-glass opacity was the most common abnormaliy on computed tomography of the chest. The Centers for Disease Control and Prevention (CDC) reported data on symptoms of COVID-19 for 291 pediatric cases, and fever and cough were shown to be the most prevalent symptoms. ${ }^{\left[{ }^{[6]}\right]}$ Similarly, in our study, we observed fever and cough as the most common symptoms, and the major CT abnormality observed was ground-glass opacities. According to available data, we can say that clinical course of pediatric patients is milder, but SARSCoV-2-positive child deaths have been described in China, the United States, and Japan. ${ }^{[17-19]}$ In our study, 2 I children were considered to have severe COVID-19, and two of them needed respiratory support, but none of the children died and all showed a favorable clinical course under supportive therapy and medical treatment according to the guideline of the Turkish Ministry of Health.

In different studies, it has been shown that the total white blood cell count is normal or decreased, and the lymphocyte count gradually decreases. ${ }^{[20,21]}$ In our study, the mean/median values of blood index parameters were within normal limits, however, there was a decrease in WBC and lymphocyte counts in some patients. C-reactive protein is increased in most patients with SARS-CoV-2 infection. ${ }^{[20,2]]}$ In our study, only 9 (42.9\%) patients had elevated C-reactive protein levels at the admission In a critical patient who needed respiratory support, the C-reactive protein level was negative at admission, but we found that it increased during follow-up. In Also, in the other patient who required respiratory support, an increase in the level of C-reactive protein was observed. Therefore, we believe that C-reactive protein should be monitored in patient groups with critical conditions. Increased levels of biochemical values including liver enzymes, muscle enzymes, and D-dimer may be seen in severe patient groups. [22] The median D-dimer was within the normal range in our study, but in some patients, it increased up to 1050 and increased during hospitalization in one of the patients who needed respiratory support.. Also, in one of these patients, we examined the high value of IL-6, an inducer of acute-phase reactant, however, we did not use anti-IL-6 therapy.Since only one patient had IL-6 result, it is difficult to assess the correlation between IL-6 level and clinical course in our study. We also recorded MPV values (mean platelet volume) in children and found them within normal ranges, however, we could not assess this result in COVID-19 due to the lack of data. In this study, we recorded all laboratory results only at the time of admission, except for two children who needed respiratory support, so it is difficult to interpret the relationship between the laboratory results and the SARS-CoV-2 infection according to our study.

The predominant chest $\mathrm{CT}$ findings in patients with COVID-19 are ground-glass opacities with or without consolidative abnormalities. ${ }^{[23,24]}$ In a multicenter study conducted in Turkey, ground-glass opacity was reported as the most common CT finding. ${ }^{[25]}$ In our study, similar to the literature, ground-glass opacities were the major abnormality on CT, II (52.4\%) patients had bilateral ground-glass opacities and $10(47.6 \%)$ patients had unilateral ground-glass opacities.

Song et al. ${ }^{[26]}$ reported four families with 24 members and showed that 22 of 24 members were infected. Similarly, in our study, $19(90.4 \%)$ patients were in close contact with confirmed cases in the family, and our results revealed that SARS-CoV-2 is transmitted quickly within the family.

There are candidate drugs fort he treatment COVID-19 and vaccine research, while there are older drugs for use as antiviral treatment that are well-known in the safety profile.

Favipiravir (FVP), a guanosine analog, has in vitro activity against RNA viruses. According to the literature, favipiravir has been used as an agent in hospitalized patients with severe influenza, Ebola, and norovirus, however, its efficacy is unclear. ${ }^{[27-29]}$ Cai et al. ${ }^{[30]}$ reported 35 patients with laboratory-confirmed COVID-19 who received oral FPV plus interferon (IFN)- $\alpha$ by aerosol inhalation and showed a shorter viral clearance time and significant improvement in radiological imaging than patients who received Lopinavir (LPV)/ritonavir (RTV) plus interferon (IFN)- $\alpha$ by aerosol inhalation. In our study, two patients received FVP and showed good clinical outcomes, but they also received supportive therapy, so it is difficult to say that this favorable outcome is associated with FVP alone. So, more clinical studies are needed to evaluate the efficacy and safety of this antiviral agent in patients with SARS-CoV-2 infection. In the study of Yayla et al. ${ }^{[3]}$ in 220 pediatric patients diagnosed with COVID-19, the rate of severe/critical patients was found to be $2.7 \%$, and favipiravir was used in 5 patients, and no side effects were reported in the patients.

The limitations of this study were; first, the number of patients in this study is not enough to discern the clinical, laboratory, radiologic findings and management of severe COVID- 19 in children. Second, it was a retrospective study and did not have a control group to compare the findingss of COVID patients. findings.

\section{CONCLUSION}

In our study, we showed a good clinical course in severe COVID-19 pediatric patients with the supportive therapy and treatment protocol of the Turkish Ministry of Health COVID-19 Pediatric Patient Management and Treatment Guideline. We believe that large-scale clinical and researches are needed in pediatric patients with severe COVID-19.

\section{Acknowledgements}

All authors have participated in the drafting of the manuscript and/or critical revision of the manuscript for important intellectual content. All authors read and approved the final manuscript. 
Ethics Committee Approval

This study approved by the Kartal Dr. Lutfi Kirdar Training and Research Hospital Clinical Research Ethics Committee (Date: 13.05.2020, Decision No: 2020/5 |4/I77/2 I).

Informed Consent

Retrospective study.

Peer-review

Internally peer-reviewed.

Authorship Contributions

Concept: A.K., C.Ç., Y.A.; Design: A.K., C.Ç.; Supervision: A.K., Y.A., R.D.; Materials: A.K., C.Ç.; Data: A.K., C.Ç., C.M.B.; Analysis: A.K., C.Ç., R.D.; Literature search: A.K., C.Ç., C.M.B.; Writing: A.K., C.Ç., Y.A.; Critical revision: A.K., Y.A.

Conflict of Interest

None declared.

\section{REFERENCES}

1. Wu P, Hao X, Lau EHY, Wong JY, Leung KSM, Wu JT, et al. Realtime tentative assessment of the epidemiological characteristics of novel coronavirus infections in Wuhan, China, as at 22 January 2020. Euro Surveill 2020;25:2000044. [CrossRef]

2. WHO. Naming the coronavirus disease (COVID-19) and the virus that causes it. Available at: https://www.who.int/emergencies/ diseases/novel-coronavirus-2019/technical-guidance/naming-thecoronavirus-disease-(covid-2019)-and-the-virus-that-causes-it. Accessed Nov 1, 2021.

3. WHO. Coronavirus disease 2019 (COVID-19): situation report, 51. Available at: https://apps.who.int/iris/handle/10665/331475. Accessed Nov 1, 2021.

4. Republic of Turkey Ministry of Health. COVID-19, New Coronavirus Disease. Available at: https://covid19bilgi.saglik.gov.tr/tr/. Accessed Apr 19, 2020.

5. Society of Pediatrics, Chinese Medical Association; Editorial Board, Chinese Journal of Pediatrics. Recommendations for the diagnosis, prevention and control of the 2019 novel coronavirus infection in children (first interim edition). Zhonghua Er Ke Za Zhi 2020;58:E004.

6. Liu W, Zhang Q, Chen J, Xiang R, Song H, Shu S, et al. Detection of Covid-19 in children in early January 2020 in Wuhan, China. N Engl J Med 2020;382:1370-1. [CrossRef]

7. Huang C, Wang Y, Li X, Ren L, Zhao J, Hu Y, et al. Clinical features of patients infected with 2019 novel coronavirus in Wuhan, China. Lancet 2020;395:497-506. [CrossRef]

8. Chen N, Zhou M, Dong X, Qu J, Gong F, Han Y, et al. Epidemiological and clinical characteristics of 99 cases of 2019 novel coronavirus pneumonia in Wuhan, China: a descriptive study. Lancet 2020;395:507-13. [CrossRef]

9. Zeng L, Xia S, Yuan W, Yan K, Xiao F, Shao J, et al. Neonatal earlyonset infection with SARS-CoV-2 in 33 Neonates Born to Mothers With COVID-19 in Wuhan, China. JAMA Pediatr 2020;174:7225. [CrossRef]

10. Sinha IP, Harwood R, Semple MG, Hawcutt DB, Thursfield R, Narayan O, et al. COVID-19 infection in children. Lancet Respir Med 2020;8:446-7. [CrossRef]

11. T.C. Sağlık Bakanlığı. Numune alma el kitabı. Available at: https:// hsgm.saglik.gov.tr/depo/kurumsal/plan-ve-faaliyetler/numune-alma-el-kitabi.pdf. Accessed Nov 1, 2021.
12. Türk Toraks Derneği. Çocuklarda Toplumda Gelişen Pnömoni Tanı ve Tedavi Uzlaş1 Raporu, 2009. Available at: https://turkthoracj. org/content/files/sayilar/147/buyuk/pdf_Toraksder_6331.pdf. Accessed Nov 1, 2021.

13. Ma XJ, Wang LN, Wang LB, Wang XF, Fang F, Deng L, et al. Diangosis and treatment guideline of community acquired pneumonia in children. Chin Clin Infect Dis J 2019;12:6-13.

14. T.C. Sağlık Bakanlığ1 Halk Sağlğ̆1 Genel Müdürlüğü. COVID-19 (SARS-CoV2 Enfeksiyonu) Rehberi (Bilim Kurulu Çalışması); 14 Nisan 2020.

15. Lu X, Zhang L, Du H, Zhang J, Li YY, Qu J, et al; Chinese Pediatric Novel Coronavirus Study Team. SARS-CoV-2 infection in children. N Engl J Med 2020;23;382:1663-5. [CrossRef]

16. CDC COVID-19 Response Team. Coronavirus disease 2019 in children - United States, February 12-April 2, 2020. MMWR Morb Mortal Wkly Rep 2020;69:422-6. [CrossRef]

17. Sun D, Li H, Lu XX, Xiao H, Ren J, Zhang FR, et al. Clinical features of severe pediatric patients with coronavirus disease 2019 in Wuhan: a single center's observational study. World J Pediatr 2020;16:251-9.

18. The Japan Times Ltd. COVID-19 cases near million as U.S. records death of six-week-old baby. Available at: https://www.japantimes. co.jp/news/2020/04/02/world/coronavirus-near-million-worldwide/\#.XoXwI4gzbD4. Accessed April 5, 2020.

19. The Japan Times Ltd. Infant girl in serious condition after COVID-19 infection, Yamanashi officials say. Available at: https://www.japantimes.co.jp/news/2020/04/02/national/infant-girl-serious-condition-covid-19-infection-yamanashi-officials-say/\#.XoX0qogzbD5. Accessed April 2, 2020.

20. The National Health Commission. Diagnosis and treatment scheme for coronavirus disease 2019 (Trial Version 6); Feb 18, 2020.

21. Chang D, Lin M, Wei L, Xie L, Zhu G, Dela Cruz CS, et al. Epidemiologic and clinical characteristics of novel coronavirus infections involving 13 patients outside Wuhan, China. JAMA 2020;323:1092-3.

22. Chen ZM, Fu JF, Shu Q, Chen YH, Hua CZ, Li FB, et al. Diagnosis and treatment recommendations for pediatric respiratory infection caused by the 2019 novel coronavirus. World J Pediatr 2020;16:2406. [CrossRef]

23. Shi H, Han X, Jiang N, Cao Y, Alwalid O, Gu J, et al. Radiological findings from 81 patients with COVID-19 pneumonia in Wuhan, China: a descriptive study. Lancet Infect Dis 2020;20:425-34.

24. Zhao W, Zhong Z, Xie X, and Jun Liu. Relation Between Chest CT Findings and Clinical Conditions of Coronavirus Disease (COVID-19) Pneumonia: A Multicenter Study. AJR Am J Roentgenol 2020;214;1072-7. [CrossRef]

25. Karbuz A, Akkoc G, Demirdag TB, Ciftdogan DY, Ozer A, Cakir $D$, et al. Epidemiological, clinical, and laboratory features of children with COVID-19 in Turkey. Front Pediatr 2021;9:631547. [CrossRef]

26. Song R, Han B, Song M, Wang L, Conlon CP, Dong T, et al. Clinical and epidemiological features of COVID-19 family clusters in Beijing, China. J Infect 2020;81:e26-e30. [CrossRef]

27. Sissoko D, Laouenan C, Folkesson E, M'Lebing AB, Beavogui AH, Baize S, et al; JIKI Study Group. experimental treatment with favipiravir for Ebola Virus Disease (the JIKI Trial): a historically controlled, single-arm proof-of-concept trial in Guinea. PLoS Med 2016;13:e1001967. [CrossRef]

28. Ruis C, Brown LK, Roy S, Atkinson C, Williams R, Burns SO, et al. Mutagenesis in norovirus in response to favipiravir treatment. N Engl J Med 2018;379:2173-6. [CrossRef]

29. Favié LM, Murk JL, Meijer A, Nijstad AL, van Maarseveen EM, Sikma MA. Pharmacokinetics of favipiravir during continuous venovenous haemofiltration in a critically ill patient with influenza. Antivir Ther 2018;23;457-61. [CrossRef] 
30. Cai Q, Yang M, Liu D, Chen J, Shu D, Xia J, et al. Experimental treatment with favipiravir for COVID-19: an open-label control study. Engineering (Beijing) 2020;6:1192-8. [CrossRef]
31. Cura Yayla BC, Özsürekçi Y, Aykaç K, Oygar PD, Laçinel Gürlevik $\mathrm{S}$, İlbay $\mathrm{S}$, et al. Characteristics and management of children with COVID-19 in Turkey. Balkan Med J 2020;37:341-7. [CrossRef]

\section{İstanbul'da Bir Pediatri Ünitesinde Ağır COVID-19'lu Çocukların Yönetimi: Geriye Dönük Çalışma}

Amaç: SARS-CoV-2, hem çocuklarda hem de yetişkinlerde ciddi hastalığın olası bir etkenidir. Bu çalışmada, hastanede yatan ağır çocuk COVID-19 hastalarının yönetimini değerlendirmeyi amaçladık.

Gereç ve Yöntem: Mart 2020 ile Mayıs 2020 tarihleri arasında 18 yaş altı ağır COVID- I9'lu hastanede yatan 21 çocuğun yönetimine ilişkin veriler bu çalışmaya dahil edildi.

Bulgular: Bu çalışmada 888 ayaktan ve 22 I yatan hasta olmak üzere toplam I I09 hasta toplandı. Hastanede yatan 22I çocuğun 9|'i (\%4I.I) SARS-CoV-2 için PCR pozitifti. Doksan bir COVID-I9 hastasının 2 I'i (\%23) şiddetli COVID-I9 olarak kabul edildi. Onu (\%47.6) kız, II'i (\%52.4) erkek olup, yaşları ortalama \pm standart sapma (SS) I4.4 2.7 yıl (aralık; 9 yıl-17.6 yıl) olarak saptandı. En sık başvuru semptomları ateş (\%80.9), öksürük (\%76.I), nefes darlığı (\%23.8) ve miyalji (\%23.8) idi. Yirmi bir hastanın dördünde (\%।9) altta yatan hastalık vardı. On dokuz (\%90.4) hasta ailede doğrulanmış olgularla yakın temas halindeydi. Tüm hastalarda tipik olarak akciğer bilgisayarlı tomografı (BT) bulguları vardı ve başlıca gözlenen BT anormallikleri buzlu cam opasiteleriydi. Solunum desteğine ihtiyaç duyan iki hasta favipiravir tedavisi aldı. Ortalama hastanede kalış süresi $7.34 \pm 2.65$ (5-16) gündü. Tüm hastalarda klinik iyileşme sağlandı.

Sonuç: Çocuklarda COVID-19'un yetişkinlere göre klinik seyri daha hafiftir ve daha iyi prognozu vardır ancak çocuk hasta grubunda ciddi olgular tanımlandığı ve bu hastaların yakından takip edilmesi gerektiği akılda tutulmalıdır.

Anahtar Sözcükler: Çocuklar; şiddetli COVID-19; yönetim. 